\title{
25 Years Of Science Parks In Spain: Towards A New Model Of Development
}

Ricardo Martínez-Cañas, Ph.D., University of Castilla-La Mancha, Spain Pablo Ruíz-Palomino, Ph.D., University of Castilla-La Mancha, Spain

\begin{abstract}
In the knowledge-based economy, developed and in developing countries are putting an increasingly interest on encouraging their firms to produce, exploit, transfer and apply knowledge. In this context, there seems to be a general agreement about the need to develop and strengthen networking activities using infrastructures to promote knowledge transfer between different economic actors. Science and Technology Parks (STPS) are an important part of these support infrastructures. The main objective of this paper is to analyze how STPs have evolved during the last 25 years in Spain. Therefore with available data we study how has changed their model from a "science push" in the first generation models to a "science pull" for the second generation models of Science Parks. Data from the APTE (Spanish Association of Science and Technology Parks) shows that new parks are redesigning their activities toward a third generation of STPs based on interactive local flows located in science-industry-government relations, increasingly involved with local, regional and even global innovation activities. This paper also analyzes how go-betweens and intermediaries can facilitate the interaction between firms, government and research institutions, and liaise with public and private $R \& D$ funding and venture capital organizations.
\end{abstract}

Keywords: Science Parks; Regional Development; High-Technology Clusters

\section{INTRODUCTION: WHAT ARE SCIENCE AND TECHNOLOGY PARKS?}

Q

ilicone Valley in California can be considered the first and main paradigm of what is a Science and Technology Park (STP hereafter). This miracle of regional development was originally created to support US Army activities during the second half of twentieth century and now is the leading edge example of a knowledge-based region (Castells and Hall, 1992). So, the great development undergone by the information technologies used for this project has caused a wave of imitators that try to replicate this successful model around the world (European-Commission, 2008). Developed countries consider STPs as the only way to compete against low cost economies through the production, exploitation, transference and application of knowledge (Sanz, 2003). Therefore, several thousand of STPs lay out all the world-wide geography but with not unified criteria in aspects like spontaneous or planned origin, infrastructure, definition of their activities, stage of development, principles and aims, nature and so on (European-Commission, 2008). Due to the space limitation of this paper, we only analyze what are STPs from the point of view of their model of development.

Despite there is not a completely accepted definition of what is an $\mathrm{STP}^{1}$, we based our work on the definition proposed by the Spanish Association of Science and Technology Parks (APTE, 2002) where a STP can be considered as a formal project, generally associated with a physical space, with shows the following characteristics:

\footnotetext{
${ }^{1}$ For more and different definitions it is recommended to review definitions proposed by European Union, International Association of Science Parks (IASP), Association of University Research Parks (AURP), United Kingdom Science Parks Association (UKSPA) and UNESCO among others.
} 
1. Formal and operational dealings with universities, research centers and higher educational institutions.

2. Designed to encourage the creation and growth of knowledge - based companies and other organizations belonging to the service sector, which are normally established in the park itself, with a high added value.

3. A stable managing body that promotes the transfer of technology and fosters innovation between the companies and organizations using the park.

Within this definition it can be outlined that:

- $\quad$ STPs has their own site and are offering a building with common services such as meeting rooms, an auditorium, other general corporate services, advanced telecommunications infrastructures, etc.

- Tenants can enjoy relevant support infrastructures like: university-related institutions, technology centers, laboratories, business and innovation centers, business incubators, etc.

- $\quad$ STPs promote formal and operational links with universities, research centers, and other higher educational institutions.

- $\quad$ STPs have a team of professionals that encourage technology transfer and innovation processes between the companies and organizations established in the park. Also these professionals assume the role of planning, construction, promotion, and marketing of the park. Therefore, these go-betweens are offering a great added value services for tenant firms and research institutions.

- $\quad$ STPs have mainly located new and incubated firms, technology firms and firms whose activities is related with innovation, knowledge and high technology.

Therefore, STPs can be defined as a kind of formal clusters where innovative and Research and Development $(\mathrm{R} \& \mathrm{D})$ activities are their key element. These innovative infrastructures also highlight the important role of regional clusters as one of the most important players in the knowledge based. However, regions do not always know how to exploit their potential and that is the reason why STPs are becoming a very popular policy instruments that are increasing in number constantly (Allen, 2007). In addition every STP differs from each other in terms of resources (human, social, technological and financial capital) and other factors of competitiveness including those of cluster externalities, local knowledge spill-overs and other multiplicative effects (Hansson, 2005). This difference can determine their model of development.

This paper concentrates on how STPs have evolved in Spain. Therefore, in the next section we analyze how these infrastructures have changed during the last 25 years. In the third section of the paper we have studied how has changed their model from a "science push" in first generation models, a "science pull" for the second generation model and also to a third generation model. Also we analyze how newest parks are redesigning their activities toward a third generation of STPs based on interactive local flows located in science-industry-government relations, increasingly involved with local, regional and even global innovation activities. Finally, we identify some conclusions together with future lines of research.

\section{SCIENCE PARKS EVOLUTION IN SPAIN}

STPs where originated in United States as industrial concentrations that were quickly copied by other regions (Castells and Hall, 1994).The idea of concentrating companies in one single area became increasingly important there in the mid-20th century, concretely during World War II (Zhang, 2005). Shortly after that, most innovative companies were aware that science had made a vital contribution to victory (atomic energy, radar, aeronautical developments etc.) and they decided to develop an approximation to leading universities. This is how the first science parks came about around Stanford University and Menlo Park in California both created towards 1950 (Hansson, 2005).

In Europe this phenomenon was retarded for almost twenty years. In the late 1960s, some universities in the United Kingdom, such as Cranfield and Cambridge, took action along these lines. In the first years, the growth and impact of parks was weak. Nevertheless, in the 1980s, the British government asked universities to be more collaborative with industry (Allen, 2007). This pressure led to a second wave of parks promoted by the main British universities. Growth continued during the 1990s and by then, more than half the universities already had some kind of agreement or collaboration with science parks. In France, the most significant is Sofia-Antipolis, created around 
1970. The first parks in Italy and Germany started in the early 1980s, concretely the Area Science Park in Trieste and the Technologic Park in Heidelberg.

In Spain, the first park was not created until the second half of the 1980s. The first initiative was the Zamudio Technology Park (Bilbao), created in 1985. During the nineties decade grow of Spanish STPs was slow. The great development of STPs phenomenon in Spain has been produced during this century. With latest data from APTE annual ${ }^{2}$ report actually there are 80 STPs that have had a significant and positive evolution in their number of firms and institutions located, employees (R\&D employees), turnovers and R\&D investment (see Table 1). As we can see at the end of 2010, the number of STPs has been triplicate since 2010. Also companies and institutions located were 5539, what means an average increase with respect to the previous years of about $8 \%$. The number of works was 145.155 employees, with an increase from 2009 of a $7 \%$. Of these workers, approximately a $50 \%$ have a university degree and an $18 \%$ were working in $R \& D$ activities. The turnovers of the companies were 21.475 million of Euros, having a small decrease of $0.3 \%$ due to big crisis that is suffering Spanish economy.

Table 1. STPs evolution in Spain

\begin{tabular}{|l|c|c|c|c|c|}
\hline \multicolumn{1}{|c|}{ Characteristics / Years } & $\mathbf{1 9 8 8 - 1 9 9 0}$ & $\mathbf{1 9 9 5}$ & $\mathbf{2 0 0 0}$ & $\mathbf{2 0 0 5}$ & $\mathbf{2 0 1 0}$ \\
\hline Number of STPs & 6 & 10 & 23 & 2010 & 5539 \\
\hline $\begin{array}{l}\text { Number of companies and } \\
\text { institutions located }\end{array}$ & $\begin{array}{c}\text { Data not } \\
\text { available }\end{array}$ & 430 & 25464 & 51488 & 145155 \\
\hline $\begin{array}{l}\text { Employment } \\
\text { (number of workers) }\end{array}$ & $\begin{array}{l}\text { Data not } \\
\text { available }\end{array}$ & 11360 & 4777 & 10140 & 25443 \\
\hline $\begin{array}{l}\text { R\&D Employment } \\
\text { (number of workers) }\end{array}$ & $\begin{array}{l}\text { Data not } \\
\text { available }\end{array}$ & $\begin{array}{c}\text { Data not } \\
\text { available }\end{array}$ & 3034 & 7494 & 21475 \\
\hline $\begin{array}{l}\text { Turnover } \\
\text { (millions of Euros) }\end{array}$ & $\begin{array}{l}\text { Data not } \\
\text { available }\end{array}$ & 935 & & & 275 \\
\hline
\end{tabular}

Source: APTE annual reports (2000, 2005 and 2010)

As additional data we highlight that the main sector of the companies located in the STPs in 2010, where companies with activities in information, computer science and telecommunications are a significant $23 \%$. Other important sector are engineering, consultancy and advising (16\%), medicine and health (7\%), energy and environment (5\%), agriculture, food and biotechnology (4\%), technology centers and R\&D (4\%), industrial activities (4\%), training and human resources (3\%), aeronautics and automotive (2\%), electronics (2\%) and business centers $(1 \%)$.

Annual reports also shows that STPs are one of the most important elements in the Spanish System of Science and Technology that is been actively promoted by national government since the beginning of this century. The economic support of national government and the 17 different autonomous regions that shape Spanish economy has increased from 300 million of euro in 2000 to over 1200 million of euro. Also, the evolution has been boosted for the diversity of the promoting entities that have been backing the creation and development of these infrastructures. With respect to stages of development of STPs, we can find three different stages (Sanchez, 2005):

\section{Initial phase:}

Between 1985 and 1992 eight technology parks promoted by the autonomous regions are created in Spain. The investment in these eight projects surpassed the 300 million Euros and in their development the universities did not participate initially. On the other hand, at those moments the Spanish SMEs (Small and Medium Enterprises) did not have interest by the technological development. With respect to the typology of the first parks, initially much interest in the projects of urbanization and little in the construction of buildings was put. Nevertheless, the interest by the creation of buildings made increase the presence of the state companies. One was a new type of enterprise location where the care of the image was fundamental as well as the respect by the green zones. The place also was

\footnotetext{
2 The first Annual Report made by Spanish Association of Science and Technology Parks was elaborated in 2000. This Annual Report included all data available from the origin of STPs in Spain.
} 
chosen strategically, that is to say, it looked for the proximity an airport and excellent communications. Mainly Autonomous regions were developing STPs as part of their new strategy for regional economic development.

\section{Development phase:}

From 1993 and 2000 were developed new initiatives connecting with other promoters beyond the strictly autonomic model like for example the Zona Franca de Vigo. During these years the regional map of the País Vasco is completed and the Balear government promotes the Balear Park of Technological Innovation (PARCBIT). In 1995, the universities begin to be interested in the technology parks and begin to emerge parks from a more scientist and university based scope. In 2000, most of Spanish universities (public and private) were promoting and developing science and technology parks initiatives.

\section{Expansion phase:}

From 1998 to 2010 a great economic growth takes place due to the development of the Society of the Information. Due to the spill-over results of the installation of a STPs in a determined zone, has appeared another type of promoters: the city councils, universities or even private companies. Nevertheless, the Spanish regional policies are very active and are creating regional networks of parks to form their regional systems of innovation. In several autonomous communities they are creating their own networks (We can find networks in Basque Country, Castilla y León, Cataluña, Valencia, Madrid and Andalucía). The association of STPs has different objectives but with the same common outlook: the expansion. In 2005 they started contacts with STPs in China and Brazil. Actually, as an important aspect of the expansion phase, Spanish STPs have developed a network of experienced parks managers, another which works with professionals involved in technology transfer among these parks and their companies, and another managed by APTE office of technology transfer (OTRI) responsible for establishing contacts between the scientific world and business community and which works in close collaboration with professionals in the Parks.

Through these three stages that have been developed over those 25 years of experience, now STPs are an important part of regional innovation system is transforming knowledge into wealth.

\section{TOWARDS A NEW MODEL OF STPS DEVELOPMENT}

STPs models are as diverse as individual initiatives carried out (European Commission, 2008). In any case, they all "are private organizations managed by specialized professionals, whose main aim is to increase the wealth of its community by promoting the culture of innovation and the competitiveness of its associated businesses and knowledge-based institutions. To enable these goals to be met, a Science Park stimulates and manages the flow of knowledge and technology amongst universities, $R \& D$ institutions, companies and markets; it facilitates the creation and growth of innovation-based companies through incubation and spin-off processes; and provides other valueadded services together with high quality space and facilities. (IASP, 2002).

Within this STPs definition we can difference between models like Science Parks and Research Parks. While the former denomination is the most common in Europe, the latter is widely used in the United States and Canada (Sanz, 2003). Further, science parks in Europe coexist with technology parks. There are not great differences between both concepts. The main ones probably refer to the size or the possible admission of productive activity. While a science park is of reduced size, with strong links to university and little emphasis on manufacturing activities, a technology park is medium-sized or big and allows for productive activities (IASP, 2002).

From a geographical point of view, science parks are mainly located in the United Kingdom (British model), while technology parks refer to the «Mediterranean model», typical of countries like France, Spain, Italy and Portugal. Apart from these two better known models, there are other similar concepts like Technopole, Business Park, Innovation Centre, Science City and Innovation Business Park.

From a holistic point of view and according to Annerstedt (2006) and Haselmayer (2004) there are three generations or models of STPs (see Table 2): 
- $\quad$ First Generation STPs, that are an extension of a university into a dedicated neighborhood area that includes incubating facilities for start-up firms, related business services and, as importantly, pathways into new, research-based technology (and know-how) for potential investors and other business entities. The typical mode of governance of a First Generation Science park is that of university-control through a foundation or limited company, created by the university or a related association. The innovation philosophy of a First Generation Science park is a 'linear approach' to innovation, which sees scientific results as raw material for innovative activities.

- $\quad$ Second Generation STPs that mainly are science-economy interaction institutions. Also are considered as an extension of a university (or other major R\&D facilities) into a dedicated high-tech zone. Managers respond to such business needs by making available a mix of high-quality facilities in the Park. The typical mode of governance of a Second Generation Science park is that of a privately-owned company which manages the Park. Academic or other research representatives must be involved with local or regional policymakers. The innovation philosophy of a Second Generation Science Park is 'demand pull' where research results and techno-scientific findings are regarded as 'raw materials' for the Park's innovating firms.

- $\quad$ Third Generation STPs are the new model among the current evolution of STPs. Generally are located within a vibrant urban community and are perceived as the quintessence of science-industry-government relations, increasingly functional and specialized along with its participation in local, regional and even global innovation activities. The objective is to increase the wealth of the whole community that the Park serves by promoting science-industry-government relations in a number of ways. The typical mode of governance is long-term public-private partnerships, where strategic decisions regarding the Park's operations are agreed through joint decisions, while the day-to-day operations could be carried out by a highly-specialized limited company. The innovation philosophy is cluster-oriented 'interactive innovation'. It is both 'science push' and 'market-pull'.

Table 2. Models of STPs development

\begin{tabular}{|l|l|l|l|}
\hline & \multicolumn{1}{|c|}{$\mathbf{1}^{\text {st }}$ generation STPs } & \multicolumn{1}{c|}{$\mathbf{2}^{\text {nd }}$ generation STPs } & \multicolumn{1}{c|}{$\mathbf{3}^{\text {rd }}$ generation STPs } \\
\hline Nature & Science push & Market pull & Interactive \\
\hline Main promoter & $\begin{array}{l}\text { Government/region/universities/ } \\
\text { private investors }\end{array}$ & $\begin{array}{l}\text { Business located in High-tech } \\
\text { zone or Technopoles }\end{array}$ & $\begin{array}{l}\text { Government, University \& } \\
\text { Industry in an urban location }\end{array}$ \\
\hline Governance & $\begin{array}{l}\text { Foundation o limited company } \\
\text { created by an University }\end{array}$ & $\begin{array}{l}\text { Privately-owned company that } \\
\text { manages the park }\end{array}$ & $\begin{array}{l}\text { Strategic decisions (owners) and } \\
\text { Day-to-day decisions (highly } \\
\text { specialized company) }\end{array}$ \\
\hline Innovation & $\begin{array}{l}\text { Linear system } \\
\text { (from Scientific to business) }\end{array}$ & $\begin{array}{l}\text { First phase of innovation } \\
\text { (Raw Innovation) }\end{array}$ & $\begin{array}{l}\text { Interactive innovation (push and } \\
\text { pull) } \\
\text { innovationted to last phase of } \\
\text { innocess }\end{array}$ \\
\hline
\end{tabular}

Source: Adapted from Annerstedt (2006)

Therefore this new emerging model of STPs operates through interactive models of innovation, embedded in diverse urban environments. In such areas, networks and systems of trust, the development of respective public, private or scientific partners, cultures of interpretation, and degrees of public or institutional participation as well as the availability of financial/legal instruments all form an integral part of the innovation environment's global function (Annerstedt, 2006). Location embeddings is no longer just a feature, but a key success factor (Haselmeyer 2004).

Other key successful factors and best practices that these third generation STPs must take care are also considered by John Allen report at Manchester Business School (2007):

- $\quad$ Born as a global project to overcome a limited regional or local scope.

- $\quad$ Be part of a sustainable community and also to be a sustainable business.

- $\quad$ Have a long-term strategy with clear objectives.

- Be a gateway to innovation and not a destination.

- $\quad$ Be managed to optimize serendipity 
- $\quad$ Be developed to aid creativity, interaction and innovation.

- $\quad$ Grow a strong two-way relationship with the associated university.

- $\quad$ Build active networks of all kinds and at all levels.

- $\quad$ Establish an understanding of each tenant's needs

- $\quad$ Offer incubation facilities either directly or indirectly

\section{CONCLUSIONS AND FUTURE LINES OF RESEARCH}

As a brief resume, we can conclude that encouraging STPs infrastructures are key for competiveness in the knowledge-based economy. Successful examples around the world have helped to countries and regions to realize that create a intellectual context where produce, exploit, transfer and apply knowledge in a globalized world need to be based and strengthen on networking activities that are rapidly evolving toward a more "interactive" model where knowledge is created, transferred and applied located in science-industry-government relations, increasingly involved with local, regional and even global innovation activities. This paper has analyzed how STPs are high value intermediaries can facilitate the interaction between firms, government and research institutions.

With this paper we start a new line of research based on how interactive relationships among economic agents located inside parks can be the essence of value creation. The management of all these intangible resources we think that could be related with the adoption of go-betweens activities to increase STPs success. Therefore, subsequent analysis will provide more in-depth knowledge of the real value of STPs infrastructure.

\section{AUTHOR INFORMATION}

Ricardo Martínez-Cañas, PhD in Business Management by University of Castilla-La Mancha. Assistant Professor of Management at Business Management Department. Faculty of Social Sciences of Cuenca, University of CastillaLa Mancha (Spain). E-mail: Ricardo.Martinez@uclm.es.

Research Interest: Social Capital, Science Parks, Business Ethics, Technology Management.

Pablo Ruíz-Palomino, PhD in Business Management by University of Castilla-La Mancha. Assistant Professor of Management at Business Management Department. Faculty of Social Sciences of Cuenca University of Castilla-La Mancha (Spain). E-mail: Pablo.Ruiz@uclm.es.

Research Interest: Business Ethics, Human Resource Management, Social Capital, Ethical Leadership.

\section{REFERENCES}

1. Allen, P. (2007): Third Generation Science Parks, Report from Manchester Business School. Available at www.mspl.co.uk/download.../8-msp-third-generation-science-parks.html (last access 05/04/2011)

2. $\quad$ Annerstedt, J. (2006): Science Parks and High-Tech clustering. In International Handbook On Industrial Policy. Patrizio Bianchi \& Sandrine Labory (Eds.). Edward Elgar Publishing.

3. APTE (2000): Annual Report. Malaga. Available at http://www.apte.org (last access 03/10/2011).

4. APTE (2002): Annual Report. Malaga. Available at http://www.apte.org (last access 03/10/2011).

5. APTE (2005): Annual Report. Malaga. Available at http://www.apte.org (last access 03/10/2011).

6. APTE (2010): Annual Report. Malaga. Available at http://www.apte.org (last access 03/10/2011).

7. Castells, M. and Hall, P. (1994): Technopoles of the World: the making of 21th century industrial complexes. London and New York: Routledge.

8. European Commission (2008): Regional Research Intensive Clusters and Science Parks. European Research Area: Research Programmes and Capacity. C. Saublens. Brussels.

9. Hansson, F. Husted, K. and Veestergard, J (2005): "Second generation science parks: from structural holes jockeys to social capital catalysts of the knowledge society." Technovation 25(9), 1039-1049.

10. Haselmayer, S. (2004). Why science and technology parks go urban: Towards embedded innovation environments. Urbanistica Informazioni. 10 (2), 35-46. 
11. IASP (2002): "Toward a New Agenda: Business, Social and Urban Development Impacts", XIX IASP World Conference on Science and Technology Parks. 3-6 September

12. Ondategui, J. C. (2002): "Parques Científicos e Innovación en España: 15 años de experiencia". In: Economía Industrial, 346, 147-160.

13. Sánchez, J. (2006): "El Lugar de los Parques Tecnológicos en la Valoración de los Conocimientos", Jornada Universidad e Iniciativa Emprendedora, Madrid, 27 de abril.

14. Sanz, L. (2003): Fundamentals of Science Parks: tools for regional development. Available at http://www.theinnovationhub.com/pdf/2003_biqw_sanz.pdf (last access 01/15/2011). 


\section{NOTES}

